\title{
The Development of Craft Education in Finnish Schools
}

\author{
Päivi Marjanen \& Mika Metsärinne
}

\begin{abstract}
The purpose of this article is to examine the major changes Finnish school craft has undergone and explain these changes by using societal, pedagogical and subject-driven determinants. The main sources of this research include committee reports and national curricula. Research data was classified into five periods: craft for home well-being (1866-1911), craft for civic society (1912-1945), craft for independent hard-working citizens (1946-1969), toward equality craft (1970-1993), and unlimited craft (1994-2014). The analysis show that school craft has steadily followed students', society's and the subject's different needs during these periods.
\end{abstract}

Keywords $\bullet$ craft, craft education, pedagogy, society, school history

\section{Introduction}

School craft was introduced in Finland in the late nineteenth century. From the very beginning, this school subject was called Sloyd in Nordic countries. The original creator of school craft was Finn Uno Cygnaeus, and the most well-known developer of Sloyd was Otto Salomon, who started teacher training in 1874 in Sweden. ${ }^{1}$ Craft education methods expanded from there to all over the world. ${ }^{2}$ The word Sloyd etymologically stems from the old Swedish word slögh , which stands for shrewdness, diligence, skillfulness and smartness, and the word slögher, denoting characteristics such as being handy, being deft, having professional skills and being skillful, experienced, and resourceful. " "The word can be derived from the corresponding old Icelandic word with the original meaning being something like sleight, cunning, artful, smart, crafty and clever." ${ }^{4}$ Nordic handicrafts gave guidelines for the development of a global discipline. Today, the names of subjects similar to Sloyd and craft have been

1 "When Salomon wrote about Sloyd he mainly meant woodworking for boys, but in his college there were also courses in textile work, home economics, drawing and modeling, gardening and physical education. Kajsa Borg, "What is Sloyd? A Question of Legitimacy and Identity," Journal of Research in Teacher Education 8, nos. 2-3 (2006), 34-51.

2 Lazaro M. Herrera, Cuban Sloyd: An Evolutional Approach, Theoretical Perspective and Empirical Contribution (Turku: Åbo Akademi University Press, 1998), 71; David J. Whittaker, The Impact and Legacy of Educational Sloyd: Head and Hands in Harness (London/New York: Routledge, 2014), 83-104.

3 Annika Wiklund-Engblom et al., "“Talking Tools:' Sloyd Processes Become Multimodal Stories with Smartphone Documentation," International Journal of Mobile and Blended Learning 6, no. 2 (2014), 41-57.

4 Borg (2006), 36.

Päivi Marjanen (PhD) is Director of Education at Humak University of Applied Sciences, Finland. Email:paivi.marjanen@humak.fi

Mika Metsärinne (PhD) is an Adjunct Professor at the Department of Teacher Education, University of Turku, Finland.

Email:mikmet@utu.fi 
changed to technology education or design and technology education at the school level internationally. ${ }^{5}$

In Finland, Sloyd changed from a folk culture to a school culture and finally to a science. ${ }^{6}$ The name of the school subject changed from Women's and Men's Handicrafts (1893), Girls' and Boys' Handicraft (1912) and Textile and Technical Work (1970) to Craft (1998). In this article, the concept of Finnish school craft is used to emphasise the philosophy of educative school craft and the meaning of the school subject-both of which are different from those of craft learning tasks and craft work outside the school environment.

The changing requirements for Finnish school craft have been described by using different kinds of explanation models. ${ }^{7}$ School reforms have been rationalised by invoking increased national and social responsibility, increased cultural democracy and level of further education, changes in the growing industrialisation of the economy and rising standards of living. ${ }^{8}$ Educational "isms," demands for new professional qualifications based on industrial production and civil eligibility focused on society's educational demands, describe and focus on different fields of changes in curricula. ${ }^{9}$

The research questions presented in this research are as follows: What kind of major changes have Finnish school craft undergone over time? How can these changes be seen using Lahdes' curricula determinants society, subject and student? These research questions will be answered through an investigation of committee reports and curricula 1866 to 2014 . Currently, the Finnish school system is at a crossroads. A new national curriculum was published in the spring of 2014. Goals for school craft emphasise process management and multi-materiality, which are important factors of the craft, design and technology education culture. ${ }^{10}$

David Whittaker has comprehensively described the history and internationalisation of Sloyd as a school craft. ${ }^{11}$ A broad perspective of the method of Sloyd teaching

5 See e.g., Marc J. de Vries et al. eds., Technology Education Today: International Perspectives (Münster/New York: Waxmann, 2016).

6 Juhani Peltonen, "Slöjdkultur och slöjdpedagogik: En vetenskapsteoretisk betraktelse," Nordisk Pedagogik 18, no. 2, (1999).

7 Sven Hartman, "Inledning," in Slöjd, bildning \& kultur, ed. Sven Hartman (Stockholm: Carlssons Bokförlag, 2014), 12-26.

8 See e.g., Erik Allardt, "Kansakoulu yhteiskunnallisena kehitystekijänä" [Elementary school as a social development factor], in Kansakoulu 1866-1966, ed. Antero Valtasaari, Antti Henttonen, Lauri Järvi, and Veli Nurmi (Helsinki: Otava, 1966), 130-48.

9 Different kinds of explanation models have been used to explain curriculum changes. See e.g. Christopher Pierson, Beyond the Welfare State? The New Political Economy of Welfare (Cambridge: Polity Press, 1991); Hannu Lehtonen, Palkkatyöläistyminen, kasvatuksen yhteiskunnallistuminen ja sosiaalipolitiikka: Valtiollisen perusopetuksen synnyn kvalifikaatiotaustan tarkastelua [Wage recruitment, socialisation of education and social policy: Qualification of the state basic education review] (Tampere: Tampere University,1984), 6; Tuomas Takala, Oppivelvollisuuskoulu ja yhteiskunnalliset intressit: Tutkimus kvalifikaatioihin ja koulutuskustannuksiin kohdistuvista intresseistä Suomen oppivelvollisuuskoulua koskevan koulutuspolittiisen päätöksenteon määreinä [Obligatory school and social interests: Study on qualifications and interests in educational costs as the definition of educational policy decision making in the Finnish compulsory school] (Tampere: Tampere University, 1983).

10 Perusopetuksen opetussuunnitelman perusteet 2014 [Finnish National Core Curriculum for Basic Education 2014] (Helsinki: Opetushallitus, 2014).

11 Whittaker (2014). 
created by Otto Salomon and its impact on the development of similar disciplines in other countries have been studied by June Eyestone (1992). ${ }^{12}$ From the perspective of the history of the school craft in other countries, e.g. Gísli Porsteinsson and Brynjar Ólafsson have described Sloyd as a description of Iceland's handicraft development ${ }^{13}$ and Kevin Brehony has defined the English Froebel movement's turn to Sloyd. ${ }^{14}$ From the Finnish perspective Jouko Kantola et.al. have defined the history of Finnish school craft and its relationship with the corresponding subjects in other countries. ${ }^{15}$ Moreno Herrera has also studied the roots of Nordic sloyd and its contribution to international education. ${ }^{16}$ This article is the first article in English that deals with the history of Finnish school craft for both boys and girls. The research presents the major developmental changes in the subject, containing almost the entire history of school craft.

\section{Research on curricula}

The modern curriculum can be defined as an invention of modernity that involves forms of knowledge whose functions serve to regulate and discipline the individual. ${ }^{17}$ Curricula express the progressive hopes of democracy. They also express cultural and social practices that have changed over time and space. They embody principles that govern what is to be taught and what learning is to occur. ${ }^{18}$ According to Thomas Popkewitz, curricula provide rules and standards for how societies interpret individuals' roles in the world as productive members of that society. Curricula are also seen as a technology that directs how an individual is to act, feel, talk and see the world and the self. ${ }^{19}$ Overall, curricula are seen as normative documents that are created in a collective process with a focus on basic values, a conception of learning, goals and tasks and student growth, development and learning model defining processes. $^{20}$

The main contents of the curricula in Finnish schools have remained the same throughout the history of basic education, although differences can be observed in

12 June E. Eyestone, "The Influence of Swedish Sloyd and Its Interpreters on American Art Education," Studies in Art Education 34, no.1 (1992), 28-38.

13 Gísli Porsteinsson and Brynjar Ólafsson, "Otto Salomon in Nääs and his First Icelandic Students in Nordic Sloyd," History of Education 43, no. 1 (2014), 31-49.

14 Kevin J. Brehony, “'Even Far Distant Japan’ is 'Showing an Interest:' The English Froebel Movement's Turn to Sloyd," History of Education 27, no. 3 (1998), 279-95.

15 Jouko Kantola et.al., Through Education Into the World of Work: Uno Cygnaeus, the Father of Technology Education (Jyväskylä: Jyväskylä University, 1999).

16 Lazaro Moreno Herrera, "Nordic Sloyd: Roots and Contribution to International Education.” Nordisk Pedagogik 19, no. 2 (1999), 91-97.

17 Thomas S. Popkewitz, “The Production of Reason and Power: Curriculum History and Intellectual Tradition," Curriculum Studies 29, no. 2 (1997), 131-64.

18 Thomas S. Popkewitz, "Curriculum History, Schooling and the History of the Present," History of Education 40, no. 1 (2011), 1-19.

19 Popkewitz (1997).

20 Irmeli Halinen, Arja-Sisko Holappa, and Liisa Jääskeläinen, "Opetussuunnitelmatyö ja yleissivistävän koulutuksen uudistaminen" [Curriculum design and education reform], Kasvatus, no. 2 (2013), 187-94. 
the guiding purposes of curricula. ${ }^{21}$ School subjects, which are elements of curricula, are made up of teachers and scholars attracted to differing factions and traditions within their subject's concern. These factions and traditions develop or decline as the subject evolves. School subjects can be divided into academic and non-academic subjects that have different statuses in education. The subjects represent the deep structures of curriculum differentiation at work within contemporary schools. According to Ivor F. Goodson, craft and overall practical subjects still have a low status. $^{22}$

According to Erkki Lahdes, curricula can be categorised into three groups based on the background determinants: society, subject and student. ${ }^{23}$ These determinants form the theoretical framework in this study. A typical school curriculum includes the features of each determinant so that one of them is dominant-the main focus. A student-focused curriculum emphasises pupils' areas of interest, such as emotional development and creative expression, self-realisation and self-esteem. A subject-driven curriculum, however, focuses mainly on school subject orientation with an emphasis on cognitive objectives. Desired qualities include strong reading and writing skills. Curriculum content can be defined as different forms and conceptions of knowledge. A society-oriented curriculum highlights the importance of socialisation, work education and activities outside educational institutions. A society-oriented curriculum sees school as a key objective for the community and members of society. Curricula are a part of the value debate in society through which school craft also tries to respond to new and unforeseen challenges.

\section{Method and source material}

Studies in history may adhere to many kinds of historical narratives. Two of these are the historicist tradition and the linguistic tradition. The historicist tradition focuses on actors and events, and progress is a central motif in this epistemology. It has been characterised as the products of human actions in their socially constructed and developed world. The linguistic turn moved the focus for how the objects of the world are constructed. In curriculum research, this means the focus is on systems of ideas that enable objects to be understood. ${ }^{24}$ The historical perspective for curriculum research tends to focus on teaching in schools, the organisation of teachers and pupils, the role of pupils and changes in contributions of schools to democracy through the structuring of social inequalities. ${ }^{25}$ This particular research, presented in this article, falls into the linguistic tradition because the aim is to make visible how systems of ideas are introduced and changed over time. Research focuses on changes in one specific school subject and the implications of such changes for the intended

21 Erja Vitikka, Opetussuunnitelman mallin jäsennys: Sisältö ja pedagogiikka kokonaisuuden rakentajina [Outline of the curriculum model: Content and pedagogy as constructors of the entirety] (Jyväskylä: Suomen kasvatustieteellinen seura, 2009).

22 Ivor F. Goodson, School Subjects and Curriculum Change (London: Falmer, 1993), 3.

23 Erkki Lahdes, Tavoiteoppimisen teoreettiset perusteet [Theoretical basics of goal learning] (Turku: Turun yliopisto, A:33, 1974).

24 Popkewitz (1997), 131-64. According to Popkewitz linguistic tradition focuses on how systems of ideas change over time but also how that change is related to issues of power.

25 Popkewitz (1997), 131-64. 
student outcomes. Curriculum goals express the requirements and expectations for education and school subjects.

Popkewitz has stressed that historical change should be understood as the breaks and ruptures through which systems of ideas construct the objects of schooling. ${ }^{26}$ It is essential to depict curricula development as a continuously renewing process. Pentti Renvall emphasises the demands of the historical way of thinking. Historical thinking requires researching the period to be examined and thinking in the style of the people of the period. Researchers should not be satisfied with merely collecting historical information but should place it within a wider historical whole. Therefore, splinter information should be avoided. Explaining historical information is an attempt to tell us why the past exists as such and what significance it has for the future. ${ }^{27}$ The focus is on one school subject, but the analysis include common school goals as this helps the understanding of school's general set of values.

Goodson has warned researchers not to be satisfied with describing only ideological or theoretical hopes. ${ }^{28}$ That is one reason why Lahdes' theoretical model was used in this research. This model was used to move beyond the changes in Finnish school craft by not only describing changes that have occurred. In this study, curriculum determinants are considered and selected from the general aims of Finnish school craft.

The main sources for this article were various curricula. At the beginning of the analyses, the aims of the documents were selected and categorised according to their curriculum determinants. The main sentences were chosen, and their meanings for school craft were analysed; those that were similar were combined. Then, they were analysed again and crystallised to describe major changes in Finnish school craft history (1866-2014). At the end of the analyses, these major changes were compared and discussed.

This study focuses on macro-level changes in one school subject, but changes in, for example, national-level curricula, are actively reinterpreted at the micro-level. They also interact and cause changes in subject factions, associations and communities. Table 1 shows macro-level changes in Finnish school education and curricula and committee reports that were used in this analysis.

26 Ibid.

27 Pentti Renvall, Nykyajan historiantutkimus [Modern history research] (Porvoo: WSOY, 1983).

28 Ivor F. Goodson, "Subjects for Study: Towards a Social History of Curriculum," in Defining the Curriculum: Histories and Ethnographies, ed. Ivor F. Goodson and Stephen J. Ball (London: Falmer Press, 1984), 25-44. 
Table 1. The levels of review of curriculums and committee reports

\begin{tabular}{|c|c|c|}
\hline & Important school changes & $\begin{array}{l}\text { Curricula and committe reports } \\
\text { for school crafts }\end{array}$ \\
\hline 1866 & Primary school & $\begin{array}{l}\text { Government regulation for primary } \\
\text { schools } 1866\end{array}$ \\
\hline 1881 & Craft model courses & $\begin{array}{l}\text { Super Government circular letter of edu- } \\
\text { cation service (1883) } \\
\text { Committee Report 1893:10 }\end{array}$ \\
\hline 1899 & Schoolbook committee report & $\begin{array}{l}\text { Committee Report 1899:10 } \\
\text { Committee Report 1912:10 }\end{array}$ \\
\hline 1925 & Rural primary school & Committee Report 1925:14 \\
\hline 1946 & Actual primary school & $\begin{array}{l}\text { Committee Report 1946:10 } \\
\text { Committee Report 1952:3 } \\
\text { Committee Report 1959:9. } \\
\text { Committee Report 1959:11 }\end{array}$ \\
\hline 1970 & Comprehensive school & $\begin{array}{l}\text { Committee Report 1970:A4 } \\
\text { Committee Report 1970:A5 }\end{array}$ \\
\hline 1985 & Comprehensive school curriculum & $\begin{array}{l}\text { Basics of Core Curriculum } 1985 \\
\text { Guiding book for teaching } 1988\end{array}$ \\
\hline 1994 & Comprehensive school curriculum & Basics of Core Curriculum 1994 \\
\hline 2014 & Comprehensive school curriculum & Basics of Core Curriculum 2014 \\
\hline
\end{tabular}

\section{Craft for home well-being (1866-1911)}

The Finnish school system was built as a part of the process of state formation. There were many aims for the development of the school system. ${ }^{29}$ Under the influence of liberalism, nationalism, philanthropy and societal changes, Finland provided education for children beginning in 1866 although the School Act of $1866^{30}$ did not mandate municipalities to establish public schools, but dictated the criteria for state support. In the context of school craft in schools, nationalism was highlighted. ${ }^{31}$

According to Risto Rinne, a moral code prevailed in Finnish schools from 1866 to $1911 .^{32}$ During this period, an ideal human was described with characteristics such as frugal, hard-working and energetic. ${ }^{33}$ Children's orientation to work and work

29 See e.g. Johannes Westberg et al., "State Formation and the Rise of Elementary Education at the Periphery of Europe: The Cases of Finland and Turkey 1860-1930," Journal of Educational Administration and History 50, no. 3 (2018), 133-44.

30 Kansakouluasetus [The Elementary School Act] 11 May 1866, Helsinki: Kansallisarkisto.

31 Darja Heikkilä, "Käsityön ammatillinen opetus Suomessa 1700-luvulta nykypäiviin” [Vocational education of craft in Finland from the 18th Century to the present], in Suomalaisen käsityökoulutuksen vaiheita 1700-luvulta 2000-luvulle, ed. Simo Kotilainen and Marjo-Riitta Simpanen (Jyväskylä: Kopijyvä Oy, 2003), 7-48.

32 Risto Rinne, Suomen oppivelvollisuuskoulun opetussuunnitelman muutokset vuosina 1916-1970: Opetussuunnitelman intentioiden ja lähtökohtien teoreettis-historiallinen tarkastelu [Changes in curricula for Finnish compulsory education in 1916-1970: A theoretical and historical review the background and purposes of curricula] (Turku: Turun yliopisto, 1984).

33 Irma Sulkunen, "Naisten järjestäytyminen ja kaksijakoinen kansalaisuus" [Women's organisation and dual citizenship], in Kansa liikkeessä, ed. Risto Alapuro, Ilkka Liikanen, Kerstin Smeds and Henrik Stenius (Helsinki: Kirjayhtymä, 1987), 157-75. 
equipment was considered important. ${ }^{34}$ Women's and men's handicrafts were included in the school curriculum because of the efforts of Uno Cygnaeus. The first Finnish curriculum model was subject-oriented. Uno Cygnaeus described such goals in the Elementary School Act (Kansakouluasetus 1866). ${ }^{35}$

Thanks to the personal efforts of Cygnaeus, craft was established among the subjects to be taught in elementary school. He became familiar with handicrafts especially through the works of Pestalozzi, Fröbel and Diesterweg. He realised the value of educational handicrafts during a tour of Fröbel's kindergartens and at the Wettingen seminar in Switzerland. Cygnaeus especially admired that children were allowed to work by playing in kindergarten and were given plenty of space for creativity. ${ }^{36}$ The establishment of the elementary school took place in the cross pressure of aims. According to Erik Allardt, Cygnaeus' motives were national, social and economic. ${ }^{37}$ Cygnaeus presented the Philanthropic line, whose aim was to educate poor people and give them entrepreneurial and independent attitudes. The basis of this idea was not to offer higher education, but a Christian education and practical skills and educate children for their roles in the family and society. ${ }^{38}$

School craft was designed in the spirit of Cygnaeus to meet the educational and practical needs of homes and society. According to Cygnaeus, the value of school craft is found in its alignment with the spirit of working-life education, in which abstract thinking is transformed into practical knowing. Women's and men's handicrafts were a part of training subjects that were aimed to train poor people to improve their living conditions through entrepreneurship and self-help. Cygnaeus' school reform did not only mean initiation of handicrafts. He strongly emphasised the moral and social aims of education. Betterment of the status of women, emphasis on education at home and the idea of general education for everyone were all core concepts of his program. ${ }^{39}$ The goal of school was not higher education but a Chris-

34 Saara Tuomaala, Työtätekevistä käsistä puhtaiksi ja kirjoittaviksi: Suomalaisen oppivelvollisuuskoulun ja maalaislasten kohtaaminen 1921-1939 [From working hands to clean and writing: A confluence between Finnish compulsory education and rural children, 1921-1939] (Helsinki: Suomalaisen Kirjallisuuden Seura, 2004).

35 Kansakouluasetus (1866). Charlotte Lydecken (1892) and Lilli Törnudd (1920) used the term intention for teaching. Both have been successful pioneers of school craft in early years' education. Charlotte Lydecken, Tyttöjen käsitöiden johtamisen ohjeita kansakouluja varten [Instructions for managing girls' handicrafts for elementary schools] (Helsinki: WSOY, 1892); Lilli Törnudd, Uusi küsitöiden oppikirja [New schoolbook for crafts: Craft lessons for secondary school classes] (Jyväskylä: Gummerus, 1920).

36 Aimo Halila, Suomen kansakoululaitoksen historia, Osa I: Kansanopetus ennen kansakoulua ja kansakoululaitoksen synty [History of the Finnish elementary school, part I: Folk education before the elementary school and the birth of a elementary school] (Porvoo:WSOY, 1949), 252; Taimo Iisalo, Kouluopetuksen vaiheita: keskiajan katedraalikoulusta nykyisiin kouluihin [Stages of school education: From Medieval cathedral school to current schools] (Helsinki: Otava, 1988), 120-21.

37 Allardt (1966), 130.

38 Uno Cygnaeus, "Vastine tarkastuskomitean lausuntoon ja ehdotuksiin" [Response to audit committee opinion and proposals], in Uno Cygnaeuksen kirjoitukset Suomen kansakoulun perustamisesta ja järjestämisestä, ed. G. Lönbeck (Helsinki: Kansanvalistusseura, 1910), 347-49; Sirkka Ahonen, Yhteinen koulu tasa-arvoa vai tasapäisyyttä? Koulutuksellinen tasa-arvo Suomessa Snellmannista tähän päivään [Common school - equal value or equality? Educational equality in Finland from Snellmann to this day] (Tampere: Vastapaino, 2003), 110.

39 Cygnaeus (1910); Heikkilä (2003), 7-48. 
tian education and practical skills. ${ }^{40}$ School craft was aimed at increasing individuals' economic well-being and home and improving the welfare of the whole nation. In addition to the practical benefits of the subject, it was thought to inspire the soul.

Until the 1880s, primary school curricula were planned at the school level and differed greatly between schools. The Circular Letters of the Supreme Board of Education (Koulutoimen ylihallituksen kiertokirje, 1881 and 1883) emphasised that schools required annual schedules based on the subjects' pedagogical principles. Curricula were unified and were included with example models and patterns for school craft in $1881 .^{41}$ A model series of boys' craft consisted of 70 model objects, 55 of which were woodwork. Girls were given their own model series in 1893 to help teachers' practical work in class. The model series was somewhat oppressive and was based on useful products. Products that were made in school favored local materials and needs. The girls' model series for town schools consisted of a 20-part product series. Six were for the lower grades of primary school, and 14 were for the upper grades. The series for rural schools consisted of 17 products. ${ }^{42}$ Generally, boys learned woodwork, and girls learned knitting and needlework.

For the first few decades, the goals, and especially the practice, of school craft were society-centric and focused on the basic skills that would help individuals complete everyday challenges and tasks. In addition to these practical aims that schools had for school craft, Cygnaeus emphasised the pedagogical spiritual value of school craft for everyday problem solving, activity, thrift and working skills.

One also has to remember the advanced educational student-centric aims of Cygnaeus, such as diligent and active citizenship. High-quality economic products and the process of making them were stressed as the aims of the subject. From a subject-driven point of view, school craft stressed mechanical skills, perseverance and patience. Compared to Lahdes' model, the aims were in balance although the effects of industrialisation were beginning to emerge at the end of this period.

\section{Craft for civic society (1912-1945)}

After the Finnish Civil War in 1918, it was considered necessary to expand the school system. While enrolment prior to the war had differed widely between regions, efforts were now made to enroll all school aged children. The expansion of the school was considered necessary to avoid events such as the Civil War. The idea was that school belongs to all social classes and genders. ${ }^{43}$

40 Cygnaeus (1910).

41 Koulutoimen ylihallituksen kiertokirje [Circular letter of the Supreme Board of Education] (1881 and 1883). See also Jouko Kantola, Cygnaeuksen jäljillä käsityöopetuksesta teknologiseen kasvatukseen [Cygnaeus trail from handicraft to technology education] (Jyväskylä: Jyväskylän yliopisto, 1997), 22.

42 Koulutoimen ylihallituksen antama mallisuunnitelma naiskäsitöitten opetukselle kansakouluissa 19 May 1893 [Circular letter regarding women's handicratfts in elementary schools, issued by the Supreme Board of Education].

43 Leena Koski, "Sivistystyön ihmiskäsitys: Villi-ihmisestä aikuiseksi yksilöksi" [The concept of humanity in education: From wild person to adult individual], in Valistus ja koulunpenkki: Kasvatus ja koulutus Suomessa 1860-luvulta 1960-luvulle, ed. Anja Heikkinen and Pirkko Leino-Kaukiainen (Helsinki: Suomalaisen kirjallisuuden seura, 2011), 159-83; Saara Tuomaala, "Työteliäiksi miehiksi ja naisiksi - mutta miten? Jatko-opetus 1900-luvun jakautuneessa Suomessa" [Into hard-working men and women - but how? Secondary education in divided Finland of the twentieth century], in Yhteiskuntaluokka ja sukupuoli, ed. Tarja Tolonen (Tampere: Vastapaino, 2008), 148-74. 
The law on basic education came into force in 1921. The first official curriculum was published in 1925 and introduced school subjects with goals and content. It was flexible although its guidelines and subject content were highly specific. The curriculum followed the systematic subject-specific Lehrplan Model of Herbart. However, the curriculum was a recommendation, and not all teachers followed it. Therefore, lessons varied between schools. ${ }^{44}$ Mikael Soininen, a school developer, based his objectives on values such as efficiency and usefulness. ${ }^{45}$

The purpose of school craft was to respond to new state demands. Basic school had been developed especially for workers and small-scale farmers whose education had an important role in society. Ideas such as pupils' enthusiasm were visible in the goals set for schools. ${ }^{46}$ After the First World War and the Finnish Civil War, schools were responsible for educating the working classes. This can be seen in the practical content of school subjects. Törnudd's Teacher Guide Book emphasised the idea that teaching should be adjusted to common people, which obviously refers to the society-centric aim of the prewar school to educate the working class for its role in democratic society.

According to Paula Tuomikoski-Leskelä, Finnish school craft had three themes: school work, general dexterity and educational handicrafts. ${ }^{47}$ During this period, school craft was introduced with a new model series in 1912 and a new curriculum in $1925 .{ }^{48}$ Large-scale, time-consuming sewing and knitting tasks that included clothes, for example, were replaced with smaller-scale versions, such as sewing dolls' clothes. Boys' handicrafts included woodwork, metalwork, painting and leatherwork. ${ }^{49}$

School craft belonged to the group of art subjects, thus indicating that aesthetic goals were considered important. School craft was also thought to develop and diversify the senses and thinking skills, the importance of which Cygnaeus also stressed. Goals such as motivation to work showed that one main purpose of school craft was to educate pupils in practical skills that would help them in everyday life. The importance of school craft as an educational subject was already known, but the choice of tasks more closely followed the principles of a practical life and neglected to consider that handicraft instruction must be an intermediate piece of civilisation that develops the spiritual potential. Unfortunately, this aim was not realised in practice. ${ }^{50}$

During this period, school craft products were still partly practical and useful in

44 Veli Nurmi, Kansakoulusta peruskouluun [From elementary school to comprehensive school] (Juva: WSOY, 1989).

45 Committee Report, Maalaiskansakoulujen opetussuunnitelma [Curriculum of rural elementary schools] (1925:14); Erkki Lahdes, Peruskoulun uusi opetusoppi (Helsinki: Kustannusosakeyhtiö Otava, 1982), 58.

46 Committee Report 1925:14; Lahdes (1982), 58.

47 Paula Tuomikoski-Leskelä, Taidekasvatus Suomessa I: Taidekasvatuksen teoria ja käytäntö koulupedagogiikassa 1860-luvulta 1920-luvulle [Art education in Finland I: Theory and practice of art education in school pedagogy from the 1860s to the 1920s] (Jyväskylä: Jyväskylän yliopisto, 1979), 201-5.

48 Committee Report, Kansakoulun käsityönopetus [Craft teaching of elementary school] (Helsinki: Keisarillisen senaatin kirjapaino 1912:10); Committee Report (1925:14).

49 Ibid.

50 Lilli Törnudd, Uusi käsitöiden oppikirja: Varsinaisten kansakoululuokkien tehtävät [New schoolbook for crafts: Tasks of elementary school classes] (Jyväskylä: Gummerus, 1917), 1. 
everyday life although the items produced included dolls and dolls' clothes, which link to subject-centric aims. The Committee Report on school craft was released 1912. It emphasised process in addition to product, which can be partly interpreted as moving toward student-centric aims. The aim was to guide teachers to offer more diverse processes on a smaller scale. One goal of school craft was to make products using different techniques. ${ }^{51}$ The target general dexterity changed to versatile dexterity.

After the Finnish Civil War, the Finnish school system moved in the direction of subject-centric aims, but these changes were not obvious in school craft. School craft was still based on practical values although society's demands and pedagogical and student-centric changes can be seen, at least at the theoretical level. New ideas in the Committee Report (1912) included the following: emphasis on student reflection and discovery in teaching. Goals focused on students' thinking processes in craft learning practices.

\section{Craft for independent and hard-working citizens (1946-1969)}

The economic structure of Finland changed after the Second World War. Services and industry offered new work opportunities in cities, and technological development demanded new qualifications. ${ }^{52}$ The committee set education for work, economic efficiency, vocation and country life, education for fellow citizens and education for human beings as educational goals. ${ }^{53} \mathrm{New}$ committee reports in 1946 and 1952 set economy education as a general goal regardless of school subject. School craft was categorised with practical aesthetic school subjects. ${ }^{54}$ Rinne referred to the years from 1945 to 1970 as the Citizen's Code Period. Postwar sentiment and new political structures led to the increased importance of the role played by social education in the atmosphere of compulsory schools. ${ }^{55}$

The second part of the Curriculum Committee's report on primary education (published in 1952) presented three main areas of study: school and home, school and home areas and school and youth work. These educational frames were aimed at teaching pupils the means for and stimulating their interest in cultural learning and activities. ${ }^{56}$ The curriculum of 1952 was flexible, and it was meant to be a teacher's tool for work. During the postwar era, the main school innovator was Matti Koskenniemi. Within didactics he highlighted clarity, activity, life proximity and sociability in the spirit of nationalism. ${ }^{57}$

Another noteworthy shift that occurred during this period saw the didactics and

51 Törnudd (1920), 2 .

52 Committee Report, Kansakoulun opetussuunnitelmakomitean mietintö I [Report of the National School Curriculum Committee I] (Helsinki: Valtioneuvosto, 1946:10).

53 Nurmi (1989), 181.

54 Committee Report (1946:10); Committee Report. Kansakoulun opetussuunnitelmakomitean mietintö II [Report of the National School Curriculum Committee II] (Helsinki: Valtioneuvoston kirjapaino, 1952:3).

55 Rinne (1984); Erkki Lahdes, Uuden koulun vaikutus Suomen kansakouluun (Helsinki: Kustannusosakeyhtiö Otava, 1961), 221-22.

56 Nurmi (1989), 183.

57 Pertti Kansanen, Didaktiikan tiedetausta [The science background of didactics] (Helsinki: Yliopistopaino, 1990). 
pedagogy of curricula no longer following previous pedagogical ideas but focused more on subject-separated learning. ${ }^{58}$ Different learners and teaching methods were taken into account in the Committee Report of 1952, but the main goal of schools was to provide democratic citizens with qualifications for future society. ${ }^{59}$ The Committee Report did not mandate any changes in the craft curricula.

Goals were focused on work, the economy, professions and the surrounding society. Overall educational aims, which emphasised independence, diligence, understanding and wisdom, were also school craft aims. ${ }^{60}$ Tyyne Valve stressed that school craft was meant to be practical and social. It should focus on practical, everyday skills ${ }^{61}$ and provide students with the skills necessary for everyday life, such as an appreciation of physical work, independence and frugality. By making things by hand, children were encouraged to respect working with their hands.

Alli Kallioniemi emphasised the importance of making an effort, when selecting production objects, to explain why these products are important and what the meaning of the product is to the pupils. This motivates children to work. ${ }^{62}$ This point could be why the theoretical background was given more attention in school craft. Skills learned in school craft were applied to various materials and purposes. Instead of making new products, maintenance work, such as patching and darning in textile craft and repairing and servicing machines in technical craft, were considered more important. ${ }^{63}$ Products made at school were mostly practical products for the home, such as tablecloths. The goals and content of school craft were also practical and focused on home products and technical skills needed at home and in society.

\section{Toward equality craft (1970-1993)}

Finland changed from a poor agricultural society to an industrial and service society during the 1950 s and 1960 s. ${ }^{64}$ In 1970 , the curriculum was based on societal values such as equality and democracy. The main school goals were pupils' distinctive personalities and pupils as responsible members of society. ${ }^{65}$ According to Rinne, an individual's code can be found in the 1970-1985 curricula. The first comprehensive school curriculum was not very clear as it consisted of two different documents, and the role and guidance value of these documents were considered contradictory. The 1984 curriculum appeared to have the same problems. ${ }^{66}$

The learning goals of this era focused on subject-specific skills rather than gen-

58 Lahdes (1982).

59 Committee Report (1952:3).

60 Committee Report (1952:3); Tyyne Valve, "Kansakoulun käsityönopetus koulukokonaisuuden osana" [School craft of the elementary school as part of the school's whole], in Kansakoulun työtapoja III osa, ed. K. Saarialho and Matti Koskenniemi (Porvoo: WSOY, 1955), 234-39.

61 Valve (1955), 234-39.

62 Alli Kallioniemi, Käsityönopetus: Merkitys - tarkoitus - metodi [Craft education: Meaning - purpose - method] (Porvoo: WSOY, 1950), 19.

63 Committee Report 1946:10.

64 Ahonen (2003), 22.

65 Committee Report, Peruskoulun opetussuunnitelmakomitean mietintö I: Opetussuunnitelman perusteet [Comprehensive School Curriculum Committee Report I: Curriculum basics] (Helsinki: valtion painatuskeskus, 1970:A4); Committee Report, Peruskoulun opetussuunnitelmakomitean mietintö II: Oppiaineiden opetussuunnitelmat [Comprehensive School Curriculum Committee Report II: Curriculum basics] (Helsinki: Valtion painatuskeskus, 1970:A5).

66 Rinne (1984). 
eral skills. ${ }^{67}$ Goals of school craft followed the prevalent general goals of the 1970 s curriculum. ${ }^{68}$ These general school goals had seven sections that included work by hand and practical skills. In this context, school craft supported the development of personality and mental health, aesthetics and ethical objectives.

Boys' and Girls' Handicraft was renamed Textile Work and Technical Work. The new name meant that the subject was no longer based on gender, but on materials. Genderless content of textile and technical work was among the general school goals. ${ }^{69}$ Textile work emphasised artistic and technical design for manufacturing. Technical work emphasised expanding student's technological worldview and increasing the learning of new technological skills-electronic and computer-aided design (CAD), for example. A common feature was increasing the role of cognitive skills through implementation.

The development of a distinctive personality was one of the goals of the subject. School craft was considered a part of general education. Similar goals were presented in the 1985 curriculum. The school system gave school craft new diverse goals. Although individual everyday life skills played an important role, social skills and working skills were also mentioned. The school craft goals included the same skills that Cygnaeus mentioned in the 1800s, although more focus was placed on designing objects.

According to Lahdes, the Committee Report reflected the movement of schools toward a more student-centric approach. ${ }^{70}$ School craft goals followed the same development. The value of school craft was based less on the production of everyday products than in previous periods. Overall, the meaning of school craft changed significantly. Pupils' choices, processes and creativity were emphasised in curriculum goals along with individualisation.

\section{Unlimited craft (1994-2014)}

The automation of society, changes brought by services, trade and internationalisation, created demand for a new curriculum. The state's normative role was decreased in schools, and they were given freedom, for example, to choose their daily working hours. Therefore, differences between schools increased..$^{71}$ School-specific curricula varied considerably. The shortest curriculum for school craft had only 10 sentences of text. ${ }^{72}$ The differences between schools were significant, and teaching did not correspond to the goals. ${ }^{73}$ The main focus was on joint school craft, but within the subject, an opposite transition increased with Textile Work and Technical Work.

During this period, general school goals emphasised sustainable development, cultural identity, multiculturalism, welfare promotion and civic education. At the same time, the number of school craft lessons was decreased, which proved problematic. School craft goals included appreciation of work and ecological, ethical,

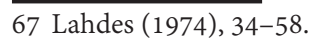

68 Committee Report (1970:A4).

69 Seija Kojonkoski-Rännäli, Ajatus käsissämme: Käsityön käsitteen merkityssisällön analyysi [The idea in our hands: The conceptual analysis of the concept of handicraft] (Turku: Turun yliopisto, 1995).

70 Lahdes (1982), 26-28.

71 Ahonen (2003), 158-200.

72 J. Mäki, “OPS - hops, hops!” [Curriculum - hops hops!], Tekstiiliopettaja, no. 4 (1993), 3.

73 Antti Hilmola, Käsityön opetuksen, suunnittelun ja toteutuksen alkuperää etsimässä [Looking for the origin of craft teaching, design and implementation] (Turku: Turun yliopisto, 2009). 
aesthetic and economic aims. Teaching was implemented as thematic topics and projects, and the focus moved to technological work education and cultural spirit. ${ }^{74}$ The constructivist conception of learning emphasised optimal learning choices and a positive desire to learn. School craft was included in the group of art and skill subjects. One theme was to integrate school craft and consumer education, which meant respect for the work and the material used.

During this period, school craft changed as Technical Work and Textile Work had been independent subjects until 1998 but lost their autonomic positions in basic education. ${ }^{75}$ Technical Work and Textile Work together now formed Diverse Craft. In Diverse Craft, the same person carries out an entire craft production from beginning to end without being restricted by the old division. ${ }^{76}$ The new core curricula in 1994 and 2004 were descriptive and gave teachers freedom to construct districtand school-level curricula. Thus, it was possible to make products using textile and technical work materials and techniques. In practice, Technical and Textile Work were taught separately because of a long-standing tradition, separate classrooms and teachers' previous education. During this period, it was still difficult to study school craft goals because of the differences between schools and districts. Nevertheless, technical and textile skills could be studied as the same discipline, although the results still showed differences. ${ }^{77}$ The similarity of the skills is based on increasing students' self-directed learning, ${ }^{78}$ which consists of different kinds of learning processes for example, in the framework of the exploratory production model. ${ }^{79}$

Between 1994-2014, school craft textbooks continued to primarily emphasise technical skills although schools had strong autonomy to develop their teaching during the period of globalisation, large-scale technological changes and new technological skills. The textbooks focused on subject-centric skills and did not reflect the changes in school craft.

74 Peruskoulun opetussuunnitelman perusteet [National Core Curriculum for Basic Education] (Helsinki: Opetushallitus, 1994), 104.

75 Juhani Peltonen, "Katosiko tekninen työ Turun yliopistosta?" [Did technical work disappear from University of Turku?], in Katosiko tekninen työ Turun yliopistosta? \& Käsityön oppimisen innovointi, ed. Mika Metsärinne and Juhani Peltonen, Techne series A:11, Research in Sloyd Education and Craft Science (Turku: Turun yliopisto, 2007), 17-33.

76 Cf. Päivi Marjanen, Koulukäsityö vuosina 1866-1984: Kodin hyvinvointiin kasvattavista tavoitteista kohti elämänhallinnan taitoja [School craft in 1866-1984: From the goals of home welfare to life management skills] (Turku: Turun yliopisto, 2012); Mika Metsärinne, Suomen koulukäsityön neljä aikakautta opetussuunnitelmien ja teknisen työn oppikirjojen kuvauksena - kohti monipuolista koulukäsityön tutkimusta ja käytänteitä [Four school sloyd periods of Finland by description of curriculums and technical work schoolbooks - toward multilateral school sloyd research and practice], Techne Series, A:13 (Turku: Turun yliopisto, 2008).

77 See e.g., Mika Metsärinne and Manne Kallio, "Experiences of Classroom Techniques and Technology Learning Outcomes," Design and Technology Education: An International Journal 19, no. 3 (2014), 9-22.

78 Mika Metsärinne, Manne Kallio and Kalle Virta," Pupils' Readiness for Self-Regulated Learning in the Forethought Phase of Exploratory Production," International Journal of Technology and Design Education 25, no. 1 (2015), 85-108.

79 Mika Metsärinne and Manne Kallio, "Theories of the Exploratory Production," Australasian Journal of Technology Education 4 (2017). 


\section{Conclusion}

Finnish school craft underwent major changes throughout its history. Some researchers have warned about periodical history research. According to Goodson the description of history should place more focus on a constantly recurring process. Categorisation was used for this research to show the major changes during quite a long history of school craft. Categorisation also gave researchers the possibility to compare the aims of each period. The research results were divided into five periods of school craft. This type of categorisation was used in two Finnish studies that focused on textile and technical school craft. The same type of categorisation was used in our article, "How were teachers instructed to teach contents knowledge in craft?" 80 The previous inquiries provided a starting point for more in-depth study and linking determinant analyses in the various periods.

During the first period of Finnish school craft (1866-1911), one of the main goals was to develop civic virtues, such as morality. The aims of school craft were balanced with these religious and philanthropic aims that also guided the active entrepreneurial mind. Cygnaeus understood the educational value of school craft and set other educational objectives for it, such as general dexterity, that also help in tackling everyday tasks and challenges. Cygnaeus' aims for school craft were quite revolutionary for the nineteenth century. The content was particularly related to improve the everyday life of pupils by producing useful products. Teachers' skills varied considerably, because the teachers had craftsmen backgrounds from various fields, and teaching objectives were lacking.

At the start of the twentieth century, the curriculum tradition turned to govern how children should be understood. ${ }^{81}$ Efforts to increase national identity and objectives focused on democratic citizens' skills were evident in the Finnish curriculum and the subject-level aims of school craft. The idea for educating democratic citizens was partly related to the needs of the emerging industry. During the civil war in Finland, people split into two groups which left deep scars that appeared in training so-called supreme and ordinary people. The focus of school craft shifted during 1912-1945 slightly toward society-centric aims although the school system was, overall, based on a subject-oriented model. The practical values of school craft and its role in teaching practical skills needed in everyday life emphasised cognitive and academic skills. As a new learning material, metalwork product series were introduced in schools, which responded to the new labour market skills needed in the industry.

Research conducted by Hargreaves and Goodson shows that economics and demographics are the two major societal forces that drive the historical and generational periodisation of educational change over time. ${ }^{82}$ These effects were obvious for

80 Mika Metsärinne and Päivi Marjanen, "Miten opettajia on ohjeistettu opettamaan koulukäsityön oppisisältöjä?" [How have teachers been instructed to teach school handicraft content?], in Uudistuva ja uusiutuva ainedidaktiikka, ed. Heini-Marja Pakula, Elina Kouki, Harry Silfverberg and Eija Yli-Panula (Turku: Turun yliopisto, 2016), 344-59.

81 Thomas S. Popkewitz, "Curriculum History, Schooling and the History of the Present," History of Education 40, no. 1 (2011), 1-19.

82 See e.g., Andy Hargreaves and Ivor Goodson, "Educational Change Over Time? The Sustainability and Non-Sustainability of Three Decades of Secondary School Change and Continuity," Educational Administration Quarterly 42, no.1 (2006), 3-41. 
curricula in Finland from 1946 to 1969. After the Second World War, focus moved to work-life orientation, which is part of society-centric aims. New subject goals were still taken into consideration, although the theory of craft and design was also given more attention. At the time of industrialisation, the content of the subjects of school craft, especially in boys' craft, was differentiated and specialised almost as vocational training. Contents such as mechanical and electrical engineering and professional design are good examples. School craft began to carry out many kinds of technological learning tasks that were needed to learn more theoretical knowledge. The teaching of school craft met the needs of society. This is likely one reason why it is said that there are two different kinds of skills in craft education: so-called practical hand skills and theoretical technological skills.

The role of curricula changed in the 1960s and 1970s. At the same time, economic values and the language of curricula were emphasised in curriculum work as professional groups were replaced by commercial and political groups. ${ }^{83}$ Finnish comprehensive school, which started in the 1970s, were based on values such as equity and the equality of the genders. Student-centric objectives focused on school, and pupils' choices, processes and creativity were emphasised. Education in Finland moved toward student-driven premises. Rapid urbanisation and the decline of smallholders in rural areas changed the structures of Finnish society. The curriculum was reformed into a new kind of social model. The curriculum of the 1970s partly changed the function of school-based work. School craft developed in the direction of subject matter teaching. New content was included, among other changes. For example, new electronic works, plastic works and CAD were introduced in the 1980s. In 1974, the education of handicraft teachers was also transferred to universities and in 1994, an individual's main subject up to the master's degree level. Increased research showed that the production of handicrafts by using technology would prepare pupils in a deeper and individual way to understand the functions of technological systems. In this respect, the research provided broader information for school craft, by making handicrafts learned technical know-how with theoretical knowledge, inventiveness, as well as a good work attitude together with learning the information needed in learning processes.

Goodson has stressed that the third industrial revolution, a massive technological transformation, caused changes in school curricula. ${ }^{84}$ The most recent period in Finnish school craft, unlimited craft (1994-2014), was based on a constructivist conception of learning. The goals of the curricula were descriptive. In addition, Technical Work and Textile Work were combined under one subject. Today, the main goal of school craft is to encourage learners to set production goals from their own life-world to achieve meaningful instrumental learning. In this way, learning is internally valued and motivated behavior. Nevertheless, its practical aims tend to remain the same.

Curriculum determinants were considered and selected from the curriculum objectives and school craft teaching material for this article. Student-driven curricula

83 Ivor F. Goodson, “Context, Curriculum and Historical Knowledge," History of Education 43, no. 6 (2014), 768-76.

84 Ivor F. Goodson, "Patterns of Curriculum Change," in International Handbook of Educational Change, ed. Andy Hargreaves, Ann Liebermas, Michael Fullan and David Hopkins (New York: Springer Science, 2005), 231-41. 
focused mostly on students' interests. The intention of school craft in this case is to support pupils to take up craft as a learning hobby. Subject-driven curriculum determinants focus on content-stressed aims. Knowledge-based content consists mostly of product and material objectives, although it is possible to find cognitive objectives such as textile knowledge. A society-oriented curriculum stresses the general society-centric aims of school craft, such as the importance of socialisation and work education.

Table 2. The major changes of determinants according to era

\begin{tabular}{|c|c|c|c|}
\hline & Society & Student & Subject \\
\hline $\begin{array}{l}\text { Craft for Home } \\
\text { Well-being (1866- } \\
\text { 1911) }\end{array}$ & $\begin{array}{l}\text { Home well-being for } \\
\text { society } \\
\text { Poverty removing, } \\
\text { Philanthropy }\end{array}$ & $\begin{array}{l}\text { Inspiration of the soul } \\
\text { Moral education } \\
\text { Problem solving }\end{array}$ & $\begin{array}{l}\text { Practical skills for } \\
\text { everyday life }\end{array}$ \\
\hline $\begin{array}{l}\text { Craft for Civic Socie- } \\
\text { ty }(1912-1945)\end{array}$ & $\begin{array}{l}\text { Growing in civil } \\
\text { society } \\
\text { Working skills }\end{array}$ & $\begin{array}{l}\text { Thinking skills } \\
\text { Enthusiasm } \\
\text { Aesthetic }\end{array}$ & $\begin{array}{l}\text { Products for everyday } \\
\text { life }\end{array}$ \\
\hline $\begin{array}{l}\text { Craft for Indepen- } \\
\text { dent and Hard-Wor- } \\
\text { king Citizens } \\
\text { (1946-1969) }\end{array}$ & $\begin{array}{l}\text { Raising a self-employ- } \\
\text { ed and working citizen } \\
\text { Democracy }\end{array}$ & $\begin{array}{l}\text { Economical thinking } \\
\text { Aesthetic/ Technical } \\
\text { procedures } \\
\text { Physical work appre- } \\
\text { ciation }\end{array}$ & $\begin{array}{l}\text { Working with hands } \\
\text { Practical school crafts } \\
\text { Practising techniques }\end{array}$ \\
\hline $\begin{array}{l}\text { Towards Equality } \\
\text { Craft (1970-1993) }\end{array}$ & $\begin{array}{l}\text { Equality } \\
\text { Membership for } \\
\text { society }\end{array}$ & $\begin{array}{l}\text { Mental health } \\
\text { Ethics } \\
\text { Planning }\end{array}$ & $\begin{array}{l}\text { Freedom of choice } \\
\text { Genderless contents } \\
\text { Design }\end{array}$ \\
\hline $\begin{array}{l}\text { Unlimited Craft } \\
(1994-2014)\end{array}$ & $\begin{array}{l}\text { Well-being promotion } \\
\text { Cultural knowledge }\end{array}$ & $\begin{array}{l}\text { Self-initiative and } \\
\text { ingenuity } \\
\text { Ecology }\end{array}$ & $\begin{array}{l}\text { Envisioned based ex- } \\
\text { ploratory production }\end{array}$ \\
\hline
\end{tabular}

Determinants of curricula, society, subject and student, were a change to detect during Finnish school craft history. In the early years, the main role of school craft was to help people survive in everyday life. School craft supported common people during difficult periods, especially in the nineteenth century and after the Finnish Civil War and the Second World War This can especially be seen in in the society-centric goals that focused on work and surviving economically in everyday life. Individual, student-centric aims such as developing the character and personality of the pupil were evident throughout the various curricula in some way. Goals such as leisure-time interests and enthusiasm were mentioned in many curricula. These goals relate strongly to pedagogical ideas. They also show the value of school craft to individuals. Making specific products and learning everyday skills were not as important values as previously. Students' personal well-being through making by hand by learning new technologies for their own life-world and future studies was noticed. This is especially visible during the last two periods, 1970-1994 and 1994- 
2014. One likely reason for the emphasis on such aims was increasing leisure-time. Strong subject-centric determinants were the most difficult to find in Finnish school craft curricula. Although subject-centric goals were highlighted in different ways in different periods, the goals have had an instrumental value during the general educational history of school craft. This is an important factor in explaining why school craft has remained part of the curriculum. Learning and teaching materials made it possible to see this change. Students' and teachers' textbooks provided a clearer understanding of the content and focus of the subject.

According to Goodson (1993), changes in school subjects must be viewed in light of the tensions of sub-groups and traditions. These groups within the subject influence and change boundaries and priorities. The need for the subject to be viewed as a scholarly discipline impinges on the promotional rhetoric and the process of subject definition, most crucially during the establishment of the subject and discipline. Goodson gave an example from a debate about craft and technology as a way of reinstating practical curricula that have missed this point. However, there may be a disconnect between high-status academic and theoretical technology education that stands in contradiction to objectives that are more practical. Tensions between subgroups within the subject focused on school craft's practical and educational value. The main dilemma was, should school craft be more practical, support everyday life and have a strong work orientation, or should school craft be more educational. This dilemma was stressed in particular during the 1946-1970 period. The biggest tensions in school craft today exist between design and technology education. These tensions arose especially after textile work and technical work were joined together as one school subject: craft. The same kind of the development, which is related to the gender distribution of the subject's perspective, has occurred in similar subjects internationally.

This study of Finnish history of school craft in the context of school changes provided the possibility to analyse the goals of school craft over the long history of the subject. Although Lahdes' model has been mainly used in the context of common school changes, the model was applicable to school craft history. The analysis showed that school craft has always steadily followed students', society's and the subject's needs. The most common aims during the whole history of school craft were linked to the development of meaningful and useful skills for everyday life. 


\section{References}

Ahonen, Sirkka. Yhteinen koulu tasa-arvoa vai tasapäisyyttä? Koulutuksellinen tasa-arvo Suomessa Snellmannista tähän päivään [Common school - equal value or equality? Educational equality in Finland from Snellmann to this day]. Tampere: Vastapaino, 2003.

Allardt, Erik. "Kansakoulu yhteiskunnallisena kehitystekijänä" [Elementary school as a social development factor]. In Kansakoulu 1866-1966, edited by Antero Valtasaari, Antti Henttonen, Lauri Järvi and Veli Nurmi, 130-48. Helsinki: Otava, 1966.

Brehony, Kevin, J. “'Even Far Distant Japan' is 'Showing an Interest': the English Froebel Movement's Turn to Sloyd." History of Education 27, no. 3 (1998), 279-95.

Borg, Kajsa. "What is Sloyd? A Question of Legitimacy and Identity." Journal of Research in Teacher Education 8, nos. 2-3 (2006), 34-51.

Committee Report 1912:10. Kansakoulun käsityönopetus [Craft teaching of elementary school]. Helsinki: Keisarillisen senaatin kirjapaino, 1912.

Committee Report 1925:14. Maalaiskansakoulujen opetusuunnitelma [Curriculum of rural elementary schools]. Helsinki: Keisarillisen senaatin kirjapaino, 1925.

Committee Report 1946:10. Kansakoulun opetussuunnitelmakomitean mietintö I [Report of the National School Curriculum Committee I]. Helsinki: Valtioneuvosto, 1946.

Committee Report 1952:3. Kansakoulun opetussuunnitelmakomitean mietintö II [Report of the National School Curriculum Committee II]. Helsinki: Valtioneuvoston kirjapaino, 1952.

Committee Report 1970:A4. Peruskoulun opetussuunnitelmakomitean mietintö I: Opetussuunnitelman perusteet [Comprehensive School Curriculum Committee Report I: Curriculum basics]. Helsinki: Valtion painatuskeskus, 1970.

Committee Report 1970:A5. Peruskoulun opetussuunnitelmakomitean mietintö II: Oppiaineiden opetussuunnitelmat [Comprehensive School Curriculum Committee Report II: Curriculum basics]. Helsinki: Valtion painatuskeskus, 1970.

Cygnaeus, Uno. "Vastine tarkastuskomitean lausuntoon ja ehdotuksiin" [Response to audit committee opinion and proposals]. In Uno Cygnaeuksen kirjoitukset Suomen kansakoulun perustamisesta ja järjestämisestä, edited by G. Lönbeck, 345-83. Helsinki: Kansanvalistusseura, 1910.

Eyestone, June E. "The Influence of Swedish Sloyd and Its Interpreters on American Art Education." Studies in Art Education 34, no.1 (1992), 28-38.

Goodson, Ivor F. "Subjects for Study: Towards a Social History of Curriculum." In Defining the Curriculum: Histories \& Ethnographies, edited by Ivor F. Goodson and Stephen J. Ball, 25-44. London: Falmer, 1984.

Goodson, Ivor F. School Subjects and Curriculum Change. Third Edition. Studies in Curriculum History Series 20. London: Falmer, 1993.

Goodson, Ivor. F. "Patterns of Curriculum Change." In International Handbook of Educational Change, edited by Andy Hargreaves, Ann Liebermas, Michael Fullan and David Hopkins, 231-41. New York: Springer Science, 2005.

Goodson, Ivor F. "Context, Curriculum and Historical Knowledge." History of Education 43, no. 6 (2014), 768-76. 
Halila, Aimo. Suomen kansakoululaitoksen historia, Osa I: Kansanopetus ennen kansakoulua ja kansakoululaitoksen synty [History of the Finnish elementary school, part I: Folk education before the elementary school and the birth of a elementary school]. Porvoo: WSOY, 1949.

Halinen, Irmeli, Arja-Sisko Holappa, and Liisa Jääskeläinen. "Opetussuunnitelmatyö ja yleissivistävän koulutuksen uudistaminen" [Curriculum design and education reform]. Kasvatus, no. 2 (2013), 187-94.

Hargreaves, Andy and Goodson, Ivor. "Change Over Time? Educational Change Over Time? The Sustainability and Non-Sustainability of Three Decades of Secondary School Change and Continuity." Educational Administration Quarterly 42, no. 1 (2006), 3-41.

Hartman, Sven. "Inledning." In Slöjd, bildning \& kultur, edited by Sven Hartman, 12-26. Stockholm: Carlssons Bokförlag, 2014.

Heikkilä, Darja. "Käsityön ammatillinen opetus Suomessa 1700-luvulta nykypäiviin" [Vocational education of craft in Finland from the 18th Century to the present]. In Suomalaisen käsityökoulutuksen vaiheita 1700-luvulta 2000-luvulle, edited by Simo Kotilainen and Marjo-Riitta Simpanen, 7-48. Jyväskylä: Kopijyvä Oy, 2003.

Hilmola, Antti. Käsityön opetuksen, suunnittelun ja toteutuksen alkuperää etsimässä [Looking for the origin of craft teaching, design and implementation]. Turku: Turun yliopisto, 2009.

Iisalo, Taimo. Kouluopetuksen vaiheita: keskiajan katedraalikoulusta nykyisiin kouluihin [Stages of school education: From Medieval cathedral school to current schools]. Helsinki: Otava, 1988.

Kallioniemi, Alli. Käsityönopetus: Merkitys - tarkoitus - metodi [Craft education: Meaning - purpose - method]. Porvoo: WSOY, 1950.

Kansakouluasetus 11 May 1866 [The Elementary School Act]. Helsinki: Kansallisarkisto.

Kansanen, Pertti. Didaktiikan tiedetausta [The science background of didactics]. Helsinki: Yliopistopaino, 1990.

Kantola, Jouko. Cygnaeuksen jäljillä käsityöopetuksesta teknologiseen kasvatukseen [Cygnaeus trail from handicraft to technology education]. Jyväskylä: Jyväskylän yliopisto, 1997.

Kantola, Jouko, Pentti Nikkanen, Jouko Kari, and Tapani Kananoja. Through Education Into the World of Work: Uno Cygnaeus, the Father of Technology Education. Jyväskylä: Jyväskylä University, 1999.

Kojonkoski-Rännäli, Seija. Ajatus käsissämme: Käsityön käsitteen merkityssisällön analyysi [The idea in our hands: The conceptual analysis of the concept of handicraft]. Turku: Turun yliopisto, 1995.

Koski, Leena. "Sivistystyön ihmiskäsitys: villi-ihmisestä aikuiseksi yksilöksi" [The concept of humanity in education: From wild person to adult individual]. In Valistus ja koulunpenkki: Kasvatus ja koulutus Suomessa 1860-luvulta 1960-luvulle, edited by Anja Heikkinen and Pirkko Leino-Kaukiainen, 159-83. Helsinki: Suomalaisen kirjallisuuden seura, 2011.

Koulutoimen ylihallituksen kiertokirje [Circular Letter of the Supreme Board of Education]. Helsinki: Kansallisarkisto, 1881.

Koulutoimen ylihallituksen kiertokirje [Circular Letter of the Supreme Board of Education]. Helskinki: Kansallisarkisto, 1883. 
Lahdes, Erkki. Uuden koulun vaikutus Suomen kansakouluun [The impact of the new school on the Finnish elementary school]. Helsinki: Kustannusosakeyhtiö Otava, 1961.

Lahdes, Erkki. Tavoiteoppimisen teoreettiset perusteet [Theoretical basics of goal learning]. Turku: Turun yliopisto A:33, 1974.

Lahdes, Erkki. Peruskoulun uusi opetusoppi [New teaching of comprehensive school]. Helsinki: Kustannusosakeyhtiö Otava, 1982.

Lehtonen, Hannu. Palkkatyöläistyminen, kasvatuksen yhteiskunnallistuminen ja sosiaalipolitiikka: Valtiollisen perusopetuksen synnyn kvalifikaatiotaustan tarkastelua [Wage recruitment, socialisation of education and social policy: Qualification of the state basic education review]. Tampere: Tampere University, 1984.

Lydecken, Charlotte. Tyttöjen käsitöiden johtamisen ohjeita kansakouluja varten [Instructions for managing girls' handicrafts for elementary schools]. Helsinki: WSOY, 1892.

Marjanen, Päivi. Koulukäsityö vuosina 1866-1984: Kodin hyvinvointiin kasvattavista tavoitteista kohti elämänhallinnan taitoja [School craft in 1866-1984: From the goals of home welfare to life management skills]. Turku: Turun yliopisto, 2012.

Metsärinne, Mika. Suomen koulukäsityön neljä aikakautta opetussuunnitelmien ja teknisen työn oppikirjojen kuvauksena - kohti monipuolista koulukäsityön tutkimusta ja käytänteitä [Four school sloyd periods of Finland by description of curriculums and technical work schoolbooks - toward multilateral school sloyd research and practice]. Techne Series A:13. Turku: Turun yliopisto, 2008.

Metsärinne, Mika and Manne Kallio. "Experiences of Classroom Techniques and Technology Learning Outcomes." Design and Technology Education: An International Journal 19, no. 3 (2014), 9-22.

Metsärinne, Mika and Päivi Marjanen. "Miten opettajia on ohjeistettu opettamaan koulukäsityön oppisisältöjä?" [How have teachers been instructed to teach school handicraft content?]. In Uudistuva ja uusiutuva ainedidaktiikka, edited by Heini-Marja Pakula, Elina Kouki, Harry Silfverberg and Eija Yli-Panula, 344-59. Suomen ainedidaktisen tutkimusseuran julkaisuja 11. Turku: Turun yliopisto, 2016.

Metsärinne, Mika and Kallio, Manne. "Instructional Theories of the Exploratory Production." Australasian Journal of Technology Education 4 (2017)

Metsärinne, Mika, Kallio, Manne and Virta, Kalle. "Pupils' Readiness for Self-Regulated Learning in the Forethought Phase of Exploratory Production." International Journal of Technology and Design Education 25, no. 1 (2015), 85-108.

Mäki, J. “OPS - hops, hops!” [Curriculum - hops, hops!]. Tekstiiliopettaja, no. 4 (1993).

Moreno Herrera, Lazaro. "Nordic Sloyd: Roots and Contribution to International Education." Nordisk Pedagogik 19, no. 2 (1999), 91-97.

Moreno Herrera, Lazaro. Cuban Sloyd: An Evolutional Approach, Theorethical Perspective and Empirical Contribution. Turku: Åbo Akademi University Press, 1998.

Nurmi, Veli. Kansakoulusta peruskouluun [From elementary school to comprehensive school]. Juva: WSOY, 1989.

Peltonen, Juhani. "Slöjdkultur och slöjdpedagogik: En vetenskapsteoretisk betraktelse." Nordisk Pedagogik 18, no. 2 (1999). 
Peltonen, Juhani. "Katosiko tekninen työ Turun yliopistosta?" [Did technical work disappear from University of Turku?]. In Katosiko tekninen työ Turun yliopistosta? \& Käsityön oppimisen innovointi, edited by Mika Metsärinne and Juhani Peltonen, 17-33. Techne series A:11, Research in Sloyd Education and Craft Science. Turku: Turun yliopisto, 2007.

Peruskoulun opetussuunnitelman perusteet [National Core Curriculum for Basic Education]. Helsinki: Opetushallitus, 1994.

Perusopetuksen opetussuunnitelman perusteet 2014 [National Core Curriculum for Basic Education 2014]. Helsinki: Opetushallitus, 2014.

Popkewitz, Thomas J. "The Production of Reason and Power: Curriculum History and Intellectual Traditions." Journal of Curriculum Studies 29, no. 2 (1997), 131-64.

Popkewitz, Thomas J. "Curriculum History, Schooling and the History of the Present." History of Education 40, no. 1 (2011), 1-19.

Pierson, Christopher. Beyond the Welfare State? The New Political Economy of Welfare. Cambridge: Polity Press, 1991.

Renvall, Pentti. Nykyajan historiantutkimus [Modern history research]. Porvoo: WSOY, 1983.

Rinne, Risto. Suomen oppivelvollisuuskoulun opetussuunnitelman muutokset vuosina 1916-1970: Opetussuunnitelman intentioiden ja lähtökohtien teoreettis-historiallinen tarkastelu [Changes in curricula for Finnish compulsory education in 1916-1970: A theoretical and historical review of the background and purposes of curricula]. Turku: Turun yliopisto, 1984.

Sulkunen, Irma. "Naisten järjestäytyminen ja kaksijakoinen kansalaisuus" [Women's organisation and dual citizenship]. In Kansa liikkeessä, edited by Risto Alapuro, Ilkka Liikanen, Kerstin Smeds and Henrik Stenius, 157-75. Helsinki: Kirjayhtymä, 1987.

Tuomaala, Saara. Työtätekevistä käsistä puhtaiksi ja kirjoittaviksi: suomalaisen oppivelvollisuuskoulun ja maalaislasten kohtaaminen 1921-1939 [From working hands to clean and writing: A confluence between Finnish compulsory education and rural children, 1921-1939]. Helsinki: Suomalaisen Kirjallisuuden Seura, 2004.

Tuomaala, Saara. "Työteliäiksi miehiksi ja naisiksi - mutta miten? Jatko-opetus 1900-luvun jakautuneessa Suomessa" [Into hard-working men and women but how? Secondary education in divided Finland of the twentieth century]. In Yhteiskuntaluokka ja sukupuoli, edited by Tarja Tolonen, 148-74. Tampere: Vastapaino, 2008.

Takala, Tuomas. Oppivelvollisuuskoulu ja yhteiskunnalliset intressit: Tutkimus kvalifikaatioihin ja koulutuskustannuksiin kohdistuvista intresseistä Suomen oppivelvollisuuskoulua koskevan koulutuspolittiisen päätöksenteon määreinä [Obligatory school and social interests: Study on qualifications and interests in educational costs as the definition of educational policy decision making in the Finnish compulsory school]. Tampere: Tampere University, 1983.

Porsteinsson, Gísli and Brynjar Ólafsson. "Otto Salomon in Näs and his first Icelandic students in Nordic Sloyd." History of Education 43, no. 1 (2014), 31-49. 
Tuomikoski-Leskelä, Paula. Taidekasvatus Suomessa I: Taidekasvatuksen teoria ja käytäntö koulupedagogiikassa 1860-luvulta 1920-luvulle [Art education in Finland I: Theory and practice of art education in school pedagogy from the $1860 \mathrm{~s}$ to the 1920s]. Jyväskylä: Jyväskylän yliopisto, 1979.

Törnudd, Lilli. Uusi käsitöiden oppikirja: Varsinaisten kansakoululuokkien tehtävät [New schoolbook for crafts: Tasks of elementary school classes]. Jyväskylä: Gummerus, 1917.

Törnudd, Lilli. Uusi käsitöiden oppikirja: Käsityönopetus kansakoulun jatkoluokilla [New schoolbook for crafts: Craft lessons for secondary school classes]. Jyväskylä: Gummerus, 1920.

Valve, Tyyne. "Kansakoulun käsityönopetus koulukokonaisuuden osana" [School craft of the elementary school as part of the school's whole]. In Kansakoulun työtapoja III osa, edited by K. Saarialho and Matti Koskenniemi, 234-39. Porvoo: WSOY, 1955.

Vitikka, Erja. Opetussuunnitelman mallin jäsennys: Sisältö ja pedagogiikka kokonaisuuden rakentajina [Outline of the curriculum model: Content and pedagogy as constructors of the entirety]. Jyväskylä: Suomen kasvatustieteellinen seura, 2009.

Vries, Marc. J. de., Stefan Fletcher, Stefan Kruse, Peter Labudde, Martin Lang, Ingelore Mammes, Charles Max, Dieter Munk, Bill Nicholl, Johannes Strobel, and Mark Winterbottom, eds. Technology Education Today: International Perspectives. Center of Exellence for Technology Education (CETE), vol. 1. Münster/ New York: Waxmann, 2016.

Westberg, Johannes, Ayhan Íncirci, Merja Paksuniemi, and Tuija Turunen. "State Formation and the Rise of Elementary Education at the Periphery of Europe: The Cases of Finland and Turkey 1860-1930." Journal of Educational Administration and History 50, no. 3 (2018), 133-44.

Whittaker, David. J. The Impact and Legacy of Educational Sloyd: Head and Hands in Harness. London/New York: Routledge, 2014.

Wiklund-Engblom, Annika, Kasper Hiltunen, Juha Hartvik, Mia Porko-Hudd, and Marléne Johansson. “'Talking Tools:' Sloyd Processes Become Multimodal Stories with Smartphone Documentation." International Journal of Mobile and Blended Learning 6, no. 2 (2014), 41-57. 